Cytologia Focus:

\title{
Worldwide Research Trends on Microalgae and Recent Work in Cytologia
}

\author{
Satoko Hosokawa ${ }^{1}$ and Shigeyuki Kawano ${ }^{2 * \dagger}$ \\ ${ }^{1}$ Department of Integrated Biosciences, Graduate school of Frontier Sciences, The University of Tokyo, \\ 5-1-5 Kashiwanoha, Kashiwa, Chiba 277-8562, Japan \\ ${ }^{2}$ Functional Biotechnology PJ, Future Center Initiative, The University of Tokyo, \\ Wakashiba, Kashiwa, Chiba 277-0871, Japan
}

Received July 28, 2020; accepted August 11, 2020

\begin{abstract}
Summary The latest issue of Cytologia (Vol. 85, Issue 2) includes a regular paper on the long-awaited karyotype analysis of the primitive red alga, Cyanidioschyzon merolae 10D, by Kuroiwa et al. (2020) and a technical note by Miyagishima and Fujiwara (2020) introducing a method to induce a controllable gene expression system in $C$. merolae. In recent years, Cytologia has focused on introducing the latest research on microalgae and has published excellent papers, such as the two mentioned above. An analysis of worldwide trends in microalgae research based on a bibliometric study found that the number of published papers has increased exponentially since 1990 and 2008. The most relevant journals in this field are "Bioresource Technology" and "Algal Research." Similarly, the number of papers in Cytologia is increasing steadily. Much interest is focused on Chlorella and Chlamydomonas. The major keywords appearing in more than 1,000 articles are those related to microalgae culture, such as "biomass," "biofuels," "lipids," and their applications, or methodologies such as "bioreactor." Today, microalgae are attracting attention (i) as sources of high-value compounds such as carotenoids, polyunsaturated fatty acids and phycobiliproteins, (ii) as whole biomass used as ingredients for food and feed, (iii) as extracts or processed biomass to produce biofuel and biofertilizers, and (iv) for bioremediation to ameliorate wastewater, soil, and polluted smoke. In this paper, we focus on how algae and microalgae are treated in Cytologia.
\end{abstract}

Keywords Microalgae, Bibliometrics, Cyanidioschyzon, Chlorella, Biomass, Biofuel.

To describe the evolution and latest trends in microalgae research, a bibliometric study of worldwide trends reviewed the numbers of papers, their citations, and the most relevant journals and keywords in this field (Garrido-Cardenas et al. 2018). This confirmed that the most relevant journals in this area are "Bioresource Technology" and "Algal Research," and the numbers of papers published in both journals have increased rapidly in the last decade. Although most of the papers are published by American researchers, many come from research institutions in China, France, and Spain. The most frequently cited species are members of Chlorella and Chlamydomonas. The major keywords appearing in more than 1,000 articles are those related to microalgae culture such as "biomass," "biofuels," "lipids" and their applications or methodologies such as "bioreactor." "Biomass" appears in approximately $20 \%$ of the papers.

\section{Bibliometric analysis of publications on microalgae} Garrido-Cardenas et al. (2018) confirmed that micro-

\footnotetext{
* Corresponding author, e-mail: kawano@edu.k.u-tokyo.ac.jp

${ }^{\dagger}$ Former editor-in-chief and current editor of Cytologia and President of the Japan Mendel Society

DOI: $10.1508 /$ cytologia.85.179
}

algae biotechnology has become a very active area, and research productivity has increased exponentially in recent years, keeping pace with industrial production. The remarkable growth of this relatively new research field over the last few years has been strongly supported by the development of culture technology and the demand for microalgae-based products. Microalgae biotechnology includes both eukaryotic microalgae and prokaryotic cyanobacteria. Although they are distinct groups, the final industrial products/applications overlap, due to the chemical similarity of their principal cell components. Today, these micro-organisms are widely used (i) as sources of high-value compounds such as carotenoids, polyunsaturated fatty acids, and phycobiliproteins, (ii) as whole biomass used as ingredients for food and feed, (iii) as extracts or processed biomass to produce biofuel and biofertilizers, and (iv) for bioremediation to ameliorate wastewater, soil, and polluted smoke.

Although there has been interest in microalgae for decades, the first studies of microalgae culture under controlled conditions began in the 1950s (Fig. 1). The same trend can be seen in Cytologia; the first progress began with research on the unicellular microalgae Euglena (Ueda 1958), while a pioneering study of Spirogyra, a 


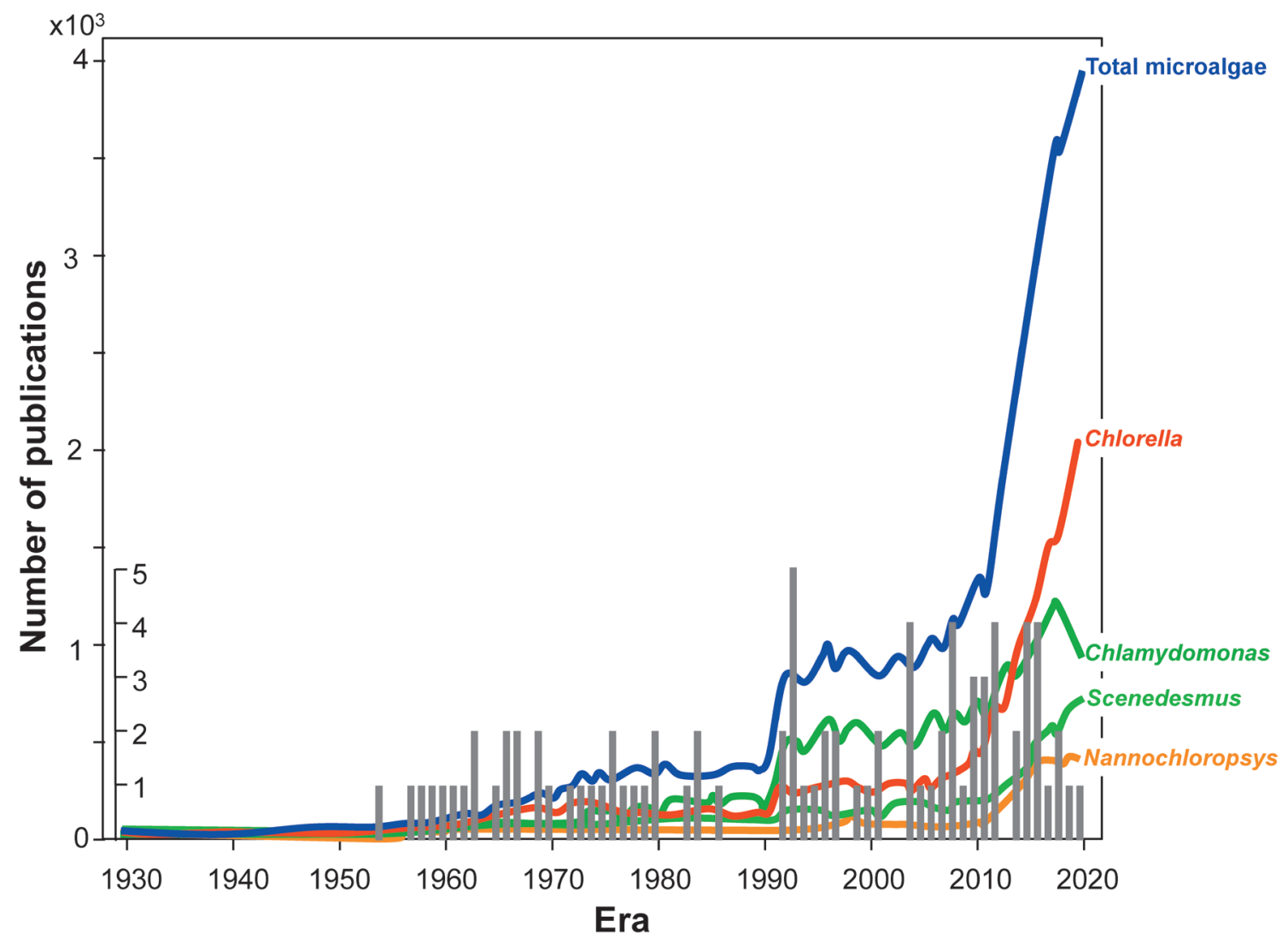

Fig. 1. The number of microalgae papers published each year in Cytologia (bar graph, inner vertical-axis). Comparison with the worldwide evolution of papers on representative microalgae strains (line graph, outer vertical-axis). The horizontal axis starts in 1929, when Cytologia was first published. These analyzes depend on the databases of "Web of Science" and "J-STAGE," which is an electronic journal platform for science and technology information in Japan.

filamentous charophyte green algae in the order Zygnematales, appeared in the 1930s (Shinke and Shigenaga 1933). Over the years, various photobioreactors have been proposed, such as raceways and tubes (Golueke and Oswald 1963), and are still frequently used today. Globally, the earliest species studied were Chlamydomonas, Chlorella, and Scenedesums, they are still the most widely cultivated today. There have been extensive physiological and genetic studies of Chlamydomonas, which is a model microorganism for photosynthesis and molecular biology studies. Chlamydomonas was first reported in Cytologia only in 1979 (Gruber and Rosario 1979).

Early microalgae products were limited to whole biomass, such as for human food or aquaculture feed. Subsequent microalgae biotechnology research had four goals: (i) to search for new strains producing novel, valuable compounds that grew rapidly and easily; (ii) to gain knowledge of the biology of strains and elucidate the mechanisms regulating cell performance; (iii) to improve production systems in terms of both efficiency and capacity; and (iv) to develop new markets and products (Richmond 2000). This was revealed in the bibliometric analysis by Garrido-Cardenas et al. (2018).
The most studied microalgae in international publications

Thousands of microalgae strains are now available from culture collections, but only a few have been studied in detail. New strains that have achieved commercial success as sources of valuable compound include Haematococcus pluvialis for astaxanthin and Dunaliella salina for beta-carotene (Leu and Boussiba 2014). However, hundreds of other strains are reported sources of carotenoids. The main reason why these strains are not suitable for large-scale commercial cultivation is their weakness in outdoor culture or poor productivity. Typically, vigorous strains are selected for outdoor culture, such as strains that are less susceptible to short-term changes in culture conditions or those that can grow in various environments. Euglena and Porphyridium, which are mainly used as dietary supplements and in cosmetics (Borowitzka 2013), are currently produced on large scales, but their production capacity remains low. The commercial use of seawater algae is gradually increasing, including Nannochloropsis, Tetraselmis, Isochrysis, and Chaetoceros species as high-quality feed for juvenile fish and crustaceans in aquaculture. Cytologia only mentions the mitochondrion-dividing ring of Nannochloropsis once (Hashimoto 2004), so studies of these microalgae for practical use are not very popular in Cytologia. 
Using biology and genetics techniques, great effort has been made to elucidate fundamental synthesis mechanisms before trying to increase target compound accumulation, focusing especially on fatty acids and astaxanthin (Han et al. 2013). Many scientists have applied methodologies developed for other organisms to microalgae but, unfortunately, those approaches have not been successful because of microalgae characteristics, such as their robust cell walls. In the early days, superproducing strains were usually selected, but the improvements achieved were limited. Subsequent attempts to screen for mutants were far from efficient, because random mutations usually revert to the wild-type after a few generations. Recently, innovations in molecular biology have made it possible to acquire stable overproducing strains (Dautor et al. 2014).

Figure 1 shows the number of papers on algae published Cytologia annually from 1929, the year it was first published, to 2019. We also investigated temporal changes in publications on major microalgae using the citation databases of "Web of Science." Globally, there were few publications on microalgae before 1950 . Numbers began to increase slowly after about 1960 and more dramatically since 1990 and 2008. The latest one might have been triggered by the Nature article "Algae bloom again” (Haag 2007). From 1960 to 1990, papers on all the microalgae examined increased moderately. After 2008, there was a remarkable increase in papers on Chlorella. Papers on other genera, divided into a group including Chlamydomonas, Scenedesmus, and Nannochloropsis, have been increasing significantly, although far fewer than on Chlorella, while there has been very little change in papers on the second group (Phaeodactylum, Isochrysis, and Spirulina).

The bibliometric analysis of all microalgae publications shows a significant increase from 1970 to 2017 , especially since 2007 (Garrido-Cardenas et al. 2018). This is consistent with the recent rapid increase in market demand for microalgae products and the rush to construct microalgae culture facilities (Forján et al. 2014). Chlorella and Chlamydomonas, studied for decades, are the genera most frequently mentioned in scientific documents. Interestingly, different genera attract attention in different countries (Garrido-Cardenas et al. 2018). For example, in the United States there is growing interest in these two genera, while in China Scenedesmus is the next most prominent after Chlorella. The most studied microalgae in Spain are Phaeodactylum and Isochrysis. Brazil is the only country where Spirulina is studied the most, although it is the seventh most commonly mentioned microalgae in a keywords analysis of research publications worldwide. Although genera such as Dunaliella, Euglena, Porphyridium, and Haematococcus are not yet widespread in academic studies, the number of publications about them should increase significantly in the near future.

\section{Microalgae first published in Cytologia}

Cytologia, which was first published in 1929, has published more than 5,800 papers (Kawano 2019). In the early years of this international journal, the first description of algae appeared in 1933. That paper first mentioned Spirogyra in Cytologia (Shinke and Shigenaga 1933). As the title "A histochemical study of plant nuclei in rest and mitosis" indicates, stained tissue samples of various plants were compared to distinguish nuclei at the two stages. For example, the thymus nucleic acid reaction was compared in Virginia spiderwort (Tradescantia ohiensis), tiger lily (Lilium tigrinum), evening primrose (Oenothera sp.), broad bean (Vicia faba), corn (Zea mays), and Marsilea quadrifolia, which is a peculiar aquatic fern with a clover-like form. The nucleus of Spirogyra did not react to thymus nucleic acid, but to a protein, in striking contrast to the other plants investigated.

In 1939, the fluidity of cytoplasmic streaming in Spirogyra was reported to be increased by a microcurrent (Northen and MacVicar 1939). Cytoplasmic streaming is the flow inside the cytoplasm that transports various molecules to organelles. Using ATP as an energy source, fluidity is generated by the interaction between actin filaments forming the cytoskeleton and the motor protein myosin. At that time, the mechanism of this phenomenon was not well understood. Research using Chara and slime molds has been ongoing since 1772, when Bonaventura Corti of Italy published his microscopic observations of the circulating cell contents. Spirogyra was considered a model cell for studying cytoplasmic streaming. Several similar papers were published subsequently (Northen 1939, Nishina et al. 1940, Yamaha and Suita 1940).

Yotsuyanagi (1953) wrote the earliest paper on Chara corallina in Cytologia, titled "Recherches sur les phénomènes moteurs dans les fragments de protoplasme isolés [Research on the active phenomenon in isolated cytoplasm]." He investigated whether cytoplasmic movement occurred in protoplasmic fragments using Chara cells separated from the cytoplasmic structure by cleaving. Sasaki (1935) reported the morphology of the spermatozoid in Chara and Nitella with reference to the structure of the motile apparatus. The earliest paper on Nitella alone was a German paper on chloroplast abnormalities in Nitella culture (Kusunoki 1944). In 1953, observations of the nucleolar organization and nucleolar organizing chromosome during mitosis in Spirogyra were reported (Oura 1953). These are the first papers on the characteristics of specific alga in Cytologia.

Spirogyra belongs to the Conjugatophyceae, which is thought to be the group most closely related to land plants, along with Charophyceae to which Nitella and Chara belong (Wodniok et al. 2011, Timme et al. 2012, Ruhfel et al. 2014, Wickett et al. 2014, O.T.P.T.I. 2019). Many researchers consider Conjugatophyceae to be 
very different organisms from other algae. In 1954, new knowledge on reproduction and reproductive cells of the freshwater alga Chaetomorpha okamurae Ueda was reported (Hirose 1954). Chaetomorpha belongs to the Phylum Chlorophyta, Class Ulvophyceae, and researchers are unanimous that it is an alga. Other studies of the Class Ulvophyceae include a study on the cytology and life-history of Cladophora uberrima Lambert, from Ranchi, India (Sinha and Ahmed 1973), a karyotype analysis of three Rhizoclonium Kütz species (Verma 1980), and the ultrastructural changes of Chaetomorpha brachygona growing in a metal environment (Chan and Wong 1987).

"Algae" is a general term for organisms that perform oxygen-generating photosynthesis, excluding mosses, ferns, and terrestrial seed plants. "Algae" used to be considered a monophyletic group of lower plants, but are now considered polyphyletic. "Microalgae" is a generic term for diverse taxa of single-cell organisms performing photosynthesis and includes polyphyletic groups. However, red algae (Rhodophyta) are thought to belong to the monophyletic Archaeplastida, together with the Glaucophyta plus the green algae (Chlorophyta) (Adl et al. 2019).

Focusing on microalgae in Cytologia, Ueda (1958) reported optical and electron microscopy examinations of the structure of pure Euglena gracilis cultures. This was the second of five papers published by Ueda in a series titled "Structure of plant cells with special reference to lower plants" from 1956 to 1961 . The others were studies of Spirogyra setiformis mitosis (Ueda 1956), the structure of Trachelomonas a genus of flagellates closely related to Euglena (Ueda 1960a), nuclear division in Oedogonium (Ueda 1960b), and a comparison of the fine structure of 21 algae chloroplasts (Ueda 1961). Subsequent studies of Euglena included papers on mitosis in Euglena acus, E. spirogyra, and E. viridis (Leedale 1959), depolymerization patterns of the nuclear constituents in the interphasic and mitotic stages of Euglena gracilis var. bacillaris treated with DNAse, RNase, trypsin, and $\alpha$-chymotrypsin in vivo (O'Donnell 1965), and nuclear changes following treatment with actinomycin D (O'Donnell-Alvelda 1967). Then, there were no papers on Euglena in Cytologia for 40 years until Sumida et al. (2007). In the 1960s, Ueda (1966) reported the fine structure of Chlorogonium elongatum (Chlorophyceae), especially the origin and development of vacuoles.

The most frequently reported microalga in Cytologia is the primitive red alga Cyanidioschyzon merolae, which is studied in 27 papers. C. merolae is a unicellular red alga with a diameter of about $1.5 \mu \mathrm{m}$ isolated from a hot spring in Italy; its cell division is easily synchronized by controlling light conditions. Therefore, research on the cell division mechanism, especially on the mitochondrial and chloroplast division machinery, has been conducted for many years. The first whole ge- nome sequence of a eukaryotic alga was completed by Kuroiwa's group (Matsuzaki et al. 2004). The second most prominent species in the microalgae papers of $\mathrm{Cy}$ tologia is Chlamydomonas reinhardtii, which is a model organism in molecular studies, especially flagellar movement, chloroplast dynamics, developmental biology, and genetics. At least 12 papers on $C$. reinhardtii have been reported in Cytologia. Since 2000, it has been possible to transform $C$. reinhardtii using selectable markers after its genome was completed, establishing it as a model organism. The culmination of this is an inducible, repressible gene expression system developed by Miyagishima and Fujiwara (2020).

\section{Cytologia today and microalgae}

Spermatophyta is prominent in Cytologia, as the subject of 70 to $83 \%$ of the papers in the last two years. The subject species are very diverse, and include more detailed studies of well-known model plants such as Arabidopsis thaliana (Hayashi et al. 2018b, Shibuta and Matsunaga 2019, Shimahara et al. 2019, Toyoda and Matsunaga 2019) and onion, Allium cepa (Barbhuiya et al. 2018, Verma and Srivastava 2018, Basu et al. 2019, Roy and Roy 2019, Tütüncü et al. 2019). Species with regional characteristics have also been reported, as pointed out in a "Cytologia Focus" two years ago (Kawano 2018).

Some examples of local plant research include the cytology of male meiosis in 17 species in 11 genera of the family Poaceae from Haryana and the Shiwalik hills (Dhaliwal et al. 2018b), a cytomorphological study of important medicinal plants of Cenchrus L. from north India (Dhaliwal et al. 2018a), a comparative karyotype analysis of five strains of Colocasia esculenta in Thailand (Senavongse et al. 2018), chromosome reports for 26 species of Asteraceae from cold deserts of the western Himalayas (Gupta et al. 2018), male meiosis in 29 species of Lamiaceae from the Sirmaur district, Himachal Pradesh, India (Singh et al. 2018), and new chromosome reports on Commelinaceae from Indian hot desert in Rajasthan (Kaur and Gupta 2018).

Two Indian research groups reported three papers on the induction of mutants of coriander Coriandrum sativum L. by gamma irradiation (Pramanik et al. 2018a, 2018b, Kumar and Pandey 2019). Coriander is an annual herb native to the eastern Mediterranean; it was one of the most commonly used herbs in ancient Greece and Rome, and is now widely used in cooking around the world. It was described in Pliny's "Naturalis Historia."

Today, the import and export of agricultural products is a major industry. Increasingly, cutting-edge technology will be applied to accelerate spice breeding. Cytologia has reported studies on stable capsaicinoid biosynthesis during fruit development in Capsicum baccatum (Sugiyama 2019) and karyotype analysis 
from aerial roots of Piper nigrum based on Giemsa and fluorochrome banding (Jha 2019). In Japan, male sterile plants were confirmed in two major domestic cultivars of Brassica rapa: "Kida-aokabu" and "Tennhoji-kabu" (Ozeki et al. 2019).

Studies in Cytologia have also examined fish chromosomes. Alongklod Tanomtong's group from Khon Kaen University, Thailand, is playing an active role. They have investigated the karyotype and chromosome characteristics of nucleolar organizing regions (NORs) in Thai fishes, including the snakeheads Channa marulius and C. marulioides (Perciformes: Channidae) (Sarasan et al. 2018), hihgfin barb, Cyclocheilichthys armatus (Cypriniformes, Cyprinidae) from the Chao Phraya River (Chaiyasan et al. 2018), and longfin carp, Labiobarbus leptocheilus (Cypriniformes, Cyprinidae) from the Mekong Basin (Saenjundaeng et al. 2018). They have also published papers on the tropical oyster Crassostrea iredalei (Ostreoida, Ostreidae) from Nakhon Si Thammarat province (Chooseangjaew et al. 2018) and black lancer, Bagrichthys majusculus (Siluriformes, Bagridae) from Nakhon Phranom and Sing Buri provinces (Supiwong et al. 2018).

The Turkish researchers Ayata and Gaffaroğlu (2019) published a chromosome study of an endemic fish, Luciobarbus kottelati (Teleostei, Cyprinidae). As model organisms, there are also technical notes on medaka,
Oryzias latipes by Watanabe-Asaka et al. (2018) and zebrafish, Danio rerio (Iwasaki and Wada 2019), which were illustrated on front covers of the journal. Other papers studied Drosophila melanogaster (Takase and Suzuki 2018, Natori and Kojima 2019) and Xenopus laevis (Nakamura and Yamamoto 2019); it is obvious that model organisms are well studied not only in plants but also in animals.

Regarding microalgae, Cytologia does not directly reflect the recent global trend and the number of papers has not increased dramatically. However, Matsunaga (2018) published a focus paper titled "Planimal cells: Artificial photosynthetic animal cells inspired by endosymbiosis and photosynthetic animals" that sets out microalgae as the most fascinating autotrophic organisms for creating planimal cells. Uchida et al. (2018) wrote a review titled "Algal genes encoding enzymes for photosynthesis and hydrocarbon biosynthesis as candidates for genetic engineering." This review focused on Botryococcus braunii and is the first mention of this species in $\mathrm{Cy}$ tologia. In addition, Ota et al. (2019) wrote an original review-style paper titled "The Parachlorella genome and transcriptome endorse active RWP-RK, meiosis and flagellar genes in trebouxiophycean algae," considering the expression of MID-related RWP-RK genes and meiosisspecific and flagellar proteins in trebouxiophycean algae. The only other microalgae paper deals with $C$. merolae



Fig. 2. Twenty years of algae biotechnology: from biofuels to functionality. A diagram showing the changes in US energy policy and trends in functional biotechnology since the Bush administration began in 2001. Largely expanded and redrawn after Yue et al. (2014). 
(Hayashi et al. 2018a). There are also reports on the marine green macroalga Chaetomorpha spiralis (Miyamura et al. 2018), the giant-celled green alga Valonia utricularis (Mine et al. 2018), the filamentous charophyte alga Klebsormidium nitens (Takano et al. 2018), and female and male gametes of the marine green alga Ulva arasakii (Miyamura et al. 2019).

\section{Algae biotechnology and Cytologia}

Microalgae are attracting attention as biofuels. The forecast international market for biofuels ranges from 756 billion to 20 trillion yen in 2035, which will create new core industries. Its raw materials have shifted from sugar cane and corn (first generation) to non-edible biomass such as cellulosic waste (second generation) and microalgae biomass (third generation). The transition was largely affected by international situations, such as food competition problems caused by the soaring oil prices during the 2003 Iraq War, the global financial crisis triggered by the collapse of Lehman Brothers in 2008, policy changes due to changes in government in major countries, and the Paris Agreement, a multilateral international agreement on climate change control, adopted at COP21 in 2015 (Fig. 2).

At the dawn of 21 st century, supported by the high crude oil price at the time, the proposal that microalgae could be a source of biofuels attracted large energy companies and huge investment in the algal biotechnology industry. A series of highly relevant papers that established the potential of these technologies was published (Fig. 1). However, the actual biodiesel production from microalgae remains distant, at theoretical values at best, and bioenergy production from microalgae has not yet been realized. Nonetheless, the significant investment made has led to a leap in technology and production capacity, which is currently driving the expansion of commercial microalgae applications.

In recent years, technology has improved. Today, there are industrial facilities with photobioreactors and raceway reactors covering hundreds of hectares. Most of the microalgae biomass produced worldwide is still produced using the outdoor raceway method (Benemann 2013). The production costs of microalgae biomass can be reduced to $5 € \mathrm{~kg}^{-1}$ and further reduced to $1 € \mathrm{~kg}^{-1}$ when combined with wastewater treatment using $\mathrm{CO}_{2}$ capture from flue gas (Acién et al. 2012). As a result, new microalgae applications focused on wastewater treatment are now scaled up for industrial processes, and the cheap biomass produced is suitable for use in low-value markets, such as biofertilizers. Hopefully, microalgae biotechnology will continue to grow steadily, improving both technology and products and expanding to new applications.

New strategies should increase the share of microalgae in the biodiesel and biojet fuel markets. In addition to their potential as a fuel source, microalgae can be used to produce high-value components for various fields. Microalgae contain useful antioxidants, natural dyes, polyunsaturated fatty acids, and other raw materials and have already been used in cosmetics, dietary supplements, feeds, etc. New functional substances have also been proposed. Over the last decade, the focus has shifted from biofuels to functionality in algae biotechnology (Fig. 2). If a biorefinery that integrates the production of biofuel and functional substances derived from microalgae can be created, it will reduce biofuel production and enable early commercialization, which will make a significant change in social systems and industrial structures.

The market for raw material algae biotechnology in Japan, so-called "new oil," has grown rapidly to 145 billion yen, while the traditional market for marine algae such as nori (laver sheet), kombu (kelp), and wakame (seaweed) (350-360 billion yen) has gradually lost its share. Docosahexaenoic (DHA, C22:6) and eicosapentaenoic (EPA, C20:5) acids are attracting the attention of the omega-3 fatty acid market (37billion yen); in addition to fish oil, DHA and EPA derived from microorganisms and microalgae are starting to appear. The micro- and macro-algae markets, mainly in the form supplements, are valued at 163.4-173.4 billion yen, while the total market in Japan was estimated to be 15,624 billion yen recently (Koyande et al. 2019, Kulshreshtha et al. 2020). The international market for functional foods and supplements is booming, but total sales of Spirulina and astaxanthin were only 389.5 billion yen, far below the level of biofuel, which is expected to reach 0.60-19 trillion yen (Ogunkunle and Ahmed 2019).

The major factors limiting the expansion of microalgae biotechnology are high production costs and the small scale of current production systems. As a result, fewer than 20,000 tonnes of biomass are produced worldwide at a cost of more than $5 € \mathrm{~kg}^{-1}$ (Borowitzka 2013). Due to the high costs, microalgae biomass is limited to the market for high-value products, such as human food and some aquaculture feed (Vigani et al. 2015). To solve these problems, more robust and efficient production systems are needed to increase production capacity exponentially. Large-scale production will significantly reduce production costs. Basic research on the breeding of microalgae strains and the value of biomass will contribute to these advances. More reports on microalgae biotechnologies in Cytologia are indispensable, such as those of Ota et al. (2014) and Takeshita et al. (2015).

\section{Acknowledgements}

We thank Mihoko Ookami very much for collecting material. This work was supported by JST-OPERA Program Grant Number JPMJOP1832, Japan. 


\section{References}

Acién, F. G., Fernández, J. M., Magán, J. J. and Molina, E. 2012. Production cost of a real microalgae production plant and strategies to reduce it. Biotechnol. Adv. 30: 1344-1353.

Adl, S. M., Bass, D., Lane, C. E., Lukeš, J., Schoch, C. L., Smirnov, A. and Cárdenas, P. 2019. Revisions to the classification, nomenclature, and diversity of eukaryotes. J. Eukaryot. Microbiol. 66: 4-119.

Ayata, M. K. and Gaffaroğlu, M. 2019. Chromosomal studies of Luciobarbus kottelati (Teleostei, Cyprinidae). Cytologia 84: 331-334.

Barbhuiya, S. N., Barhoi, D., Datta, S. K. and Giri, S. 2018. Two major components of steel fabrication industry, benzene and thinner induce cytotoxicity in Allium cepa L. root cells. Cytologia 83: $155-158$.

Basu, S. A., Datta, K., Pramanik, A., Gupta, S., Das, D., Karmakar, R. and Ghosh, B. 2019. Assessment of cytotoxicity induced by heavy metal arsenic trioxide and azo-dye metanil yellow in Allium cepa assay and aqueous plant extracts mediated amelioration. Cytologia 84: 263-269.

Benemann, J. 2013. Microalgae for biofuels and animal feeds. Energies 6: 5869-5886.

Borowitzka, M. A. 2013. High-value products from microalgaetheir development and commercialisation. J. Appl. Phycol. 25: 743-756.

Chaiyasan, P., Supiwong, W., Saenjundaeng, P., Seetapan, K., Pinmongkhonkul, S. and Tanomtong, A. 2018. A report on classical cytogenetics of hihgfin barb fish, Cyclocheilichthys armatus (Cypriniformes, Cyprinidae). Cytologia 83: 149-154.

Chan, K. and Wong, S. L. 1987. Ultrastructural changes of Chaetomorpha brachygona growing in metal environment. Cytologia 52: 97-105.

Chooseangjaew, S., Tanyaros, S., Jumrusthanasan, S., Getlekha, N. and Tanomtong, A. 2018. Karyological analysis and nucleolar organizer region of tropical oyster, Crassostrea iredalei (Ostreoida, Ostreidae) in Thailand. Cytologia 83: 129-132.

Dautor, Y., Úbeda-Mínguez, P., Chileh, T., García-Maroto, F. and Alonso, D. L. 2014. Development of genetic transformation methodologies for an industrially-promising microalga: Scenedesmus almeriensis. Biotechnol. Lett. 36: 2551-2558.

Dhaliwal, A., Dhaliwal, R. S., Kaur, N. and Gupta, R. C. 2018a. Cytomorphological study in genus Cenchrus L.: An important medicinal plant from north India (Family: Poaceae). Cytologia 83: $45-52$.

Dhaliwal, A., Kaur, N. and Gupta, R. C. 2018b. Cytology of some grasses from Haryana and Shiwalik hills. Cytologia 83: 23-30.

Forján, E., Navarro, F., Cuaresma, M., Vaquero, I., Ruíz-Domínguez, M. C., Gojkovic, Ž., Vázquez, M., Márquez, M., Mogedas, B., Bermejo, E., Girlich, S., Domínguez, M. J., Vílchez, C., Vega, J. M. and Garbayo, I. 2014. Microalgae: Fast-growth sustainable green factories. Crit. Rev. Environ. Sci. Technol. 45: 1705-1755.

Garrido-Cardenas, J. A., Manzano-Agugliaro, F., Acien-Fernandez, F. G. and Molina-Grima, E. 2018. Microalgae research worldwide. Algal Res. 35: 50-60.

Golueke, C. G. and Oswald, W. J. 1963. Power from solar energy—via algae-produced methane. Sol. Energy 7: 86-92.

Gruber, H. E. and Rosario, B. 1979. Ultrastructure of the Golgi apparatus and contractile vacuole in Chlamydomonas reinhardi. Cytologia 44: 505-526.

Gupta, R. C., Goyal, H., Goel, R. K. and Singh, V. 2018. New and varied chromosome reports in twenty-six species of the family Asteraceae from cold deserts of the western Himalaya. Cytologia 83: $215-220$.

Haag, A. L. 2007. Algae bloom again. Nature 447: 520-521.

Han, D., Li, Y. and Hu, Q. 2013. Astaxanthin in microalgae: Path- ways, functions and biotechnological implications. Algae 28: 131-147.

Hashimoto, H. 2004. Mitochondrion-dividing ring in an alga Nannochloropsis oculata (Eustigmatophyceae, Heterokonta). Cytologia 69: 323-326.

Hayashi, K., Kato, K. and Matsunaga, S. 2018a. Convolutional neural network-based automatic classification for algal morphogenesis. Cytologia 83: 301-305.

Hayashi, Y., Takagi, C. and Nishimura, M. 2018b. Existence of lipid bodies surrounded by membranes in early greening cotyledonary cells. Cytologia 83: 123-124.

Hirose, H. 1954. Studies on the morphology and behaviour of the reproductive cells of Chaetomorpha okamurai Ueda. Cytologia 19: $358-370$.

Iwasaki, M. and Wada, H. 2019. Regulation of scale morphogenesis through Wnt/PCP signaling in zebrafish. Cytologia 84: 293-294.

Jha, T. B. 2019. Karyotype analysis from aerial roots of Piper nigrum based on Giemsa and fluorochrome banding. Cytologia 84: 313-317.

Kaur, N. and Gupta, R. C. 2018. New chromosome reports in Commelinaceae from Indian hot desert Rajasthan. Cytologia 83: 259-264.

Kawano, S. 2018. Karyotype and chromosome behavior analyses in three regions of the Indomalayan realm. Cytologia 83: 223-228.

Kawano, S. 2019. History and new developments on the 90th anniversary of Cytologia: On the occasion of the publication of "Dawn of modern wheat genetics." Cytologia 84: 193-198.

Koyande, A. K., Chew, K. W., Rambabu, K., Tao, Y., Chu, D.-T. and Showa, P.-L. 2019. Microalgae: A potential alternative to health supplementation for humans. Food Sci. Hum. Well. 8: 16-24.

Kulshreshtha, G., Hincke, M. T., Prithiviraj, B. and Critchley, A. 2020. A review of the varied uses of macroalgae as dietary supplements in selected poultry with special reference to laying hen and broiler chickens. J. Mar. Sci. Eng. 8: 536-564.

Kumar, G. and Pandey, A. 2019. Cytogenetical investigation of a translocation heterozygote induced by gamma rays in Coriandrum sativum L. Cytologia 84: 211-214.

Kuroiwa, T., Yagisawa, F., Fujiwara, T., Inui, Y., Matsunaga, T. M., Katoi, S., Matsunaga, S., Nagata, N., Imoto, Y. and Kuroiwa, H. 2020. Mitotic karyotype of the primitive red alga Cyanidioschyzon merolae 10D. Cytologia 85: 107-113.

Kusunoki, S. 1944. Über chloroplasten-anomalien bei kulturen von Nitella sp. und Hydrilla verticillata. Cytologia 13: 225-236.

Leedale, G. F. 1959. Amitosis in three species of Euglena. Cytologia 24: 213-219.

Leu, S. and Boussiba, S. 2014. Advances in the production of highvalue products by microalgae. Ind. Biotechnol. 10: 169-183.

Matsunaga, S. 2018. Planimal cells: Artificial photosynthetic animal cells inspired by endosymbiosis and photosynthetic animals. Cytologia 83: 3-6.

Matsuzaki, M. et al. 2004. Genome sequence of the ultra-small unicellular red alga Cyanidioschyzon merolae. Nature 428: 653-657.

Mine, I., Suzuki, S., Li, K.-F. and Sekida, S. 2018. pH-dependent maintenance of cell wall integrity in the giant-celled green alga Valonia utricularis. Cytologia 83: 99-102.

Miyagishima, S. and Fujiwara, T. 2020. An inducible and repressible gene expression system in the unicellular red alga Cyanidioschyzon merolae. Cytologia 85: 91-92.

Miyamura, S., Ichihara, K., Yamazaki, T., Kuwano, K. and Kawano, S. 2019. Visualization of gamete mating structure of marine green alga by FE-SEM. Cytologia 84: 191-192.

Miyamura, S., Nomura, M., Mitsuhashi, F. and Nagumo, T. 2018. High-speed video analysis of the flagellar movement of isogametes during fertilization of the marine green macroalga, Chaetomorpha spiralis (Ulvophyceae, Chlorophyta). Cytologia 83: 109-114. 
Nakamura, Y. T. and Yamamoto, Y. 2019. The proximal end of the gastrocoel is on the gravity axis of the gastrula with a closing yolk plug in Xenopus laevis. Cytologia 84: 335-341.

Natori, K. and Kojima, T. 2019. Subdivision of the tarsal region into five tarsal segments by the combination of region-specific transcription factors. Cytologia 84: 105.

Nishina, Y., Sinotô, Y. and Satô, D. 1940. Effects of fast neutrons upon plants, IV cytoplasmic changes in Spirogyra. Cytologia 11: 311-318.

Northen, H. T. 1939. Studies on the protoplasmic nature of stimulation and anesthesia. Cytologia 10: 105-112.

Northen, H. T. and MacVicar, R. 1939. Studies of protoplasmic structure in Spirogyra. VI Effects of sound and electricity on elasticity. Cytologia 10: 18-22.

O'Donnell, E. H. J. 1965. Nucleolus and chromosomes in Euglena gracilis. Cytologia 30: 118-154.

O’Donnell-Alvelda, E. 1967. Nuclear changes following treatment with Actinomycin D. Cytologia 32: 568-581.

Ogunkunle, O. and Ahmed, N. A. 2019. A review of global current scenario of biodiesel adoption and combustion in vehicular diesel engines. Energy Reports 5: 1560-1579.

O.T.P.T.I. [= One Thousand Plant Transcriptomes Initiative] 2019. One thousand plant transcriptomes and the phylogenomics of green plants. Nature 574: 679-685.

Ota, S., Oshima, K., Yamazaki, T., Takeshita, T., Bišová, K., Zachleder, V., Hattori, M. and Kawano, S. 2019. The Parachlorella genome and transcriptome endorse active RWP-RK, meiosis and flagellar genes in trebouxiophycean algae. Cytologia 84: 323-330.

Ota, S., Yoshihara, M., Hirata, A. and Kawano, S. 2014. Technical note: 3D-TEM imaging demonstrating dynamic conversion of starch and oil in a cell of Chlorella sorokiniana. Cytologia 79: 287-288.

Oura, G. 1953. On the mitosis of the Spirogyra with special reference to the nucleolar organization and nucleolar organizing chromosome. Cytologia 18: 297-304.

Ozeki, M., Komatsu, K., Mitsui, Y. and Wakui, K. 2019. Genetic and cytological investigation of genic male sterility in Brassica rapa ssp. rapa 'Kida-aokabu' and 'Tennhoji-kabu.' Cytologia 84: 255-261.

Pramanik, A., Datta, A. K., Gupta, S., Ghosh, B., Das, D. and Kumbhakar, D. V. 2018a. Cadmium sulfide nanoparticles and gamma irradiations induced desynapsis with associated phenotypic marker trait in Coriandrum sativum L. (Apiaceae). Cytologia 83: 307-310.

Pramanik, A., Datta, A. K., Gupta, S., Ghosh, B., Das, D., Kumbhakar, D. V. and Hore, M. 2018b. Gamma irradiation sensitivity in $\mathrm{Co}$ riandrum sativum L. (coriander). Cytologia 83: 381-385.

Richmond, A. 2000. Microalgal biotechnology at the turn of the millennium: A personal view. J. Appl. Phycol. 12: 441-451.

Roy, A. and Roy, S. 2019. Assessment of cytotoxic effects of aqueous and methanolic leaf extracts of Clerodendrum inerme (L.) Gaertn. and C. viscosum Vent. using Allium test. Cytologia 84: 73-76.

Ruhfel, B. R., Gitzendanner, M. A., Soltis, P. S., Soltis, D. E. and Burleigh, J. G. 2014. From algae to angiosperms-inferring the phylogeny of green plants (Viridiplantae) from 360 plastid genomes. BMC Evol. Biol. 14: 23.

Saenjundaeng, P., Kaewmad, P., Supiwong, W., Pinthong, K., Pengseng, P. and Tanomtong, A. 2018. Karyotype and characteristics of nucleolar organizer regions in longfin carp, Labiobarbus leptocheilus (Cypriniformes, Cyprinidae). Cytologia 83: 265-269.

Sarasan, T., Jantarat, S., Supiwong, W., Yeesin, P., Srisamoot, N. and Tanomtong, A. 2018. Chromosomal analysis of two snakehead fishes, Channa marulius (Hamilton, 1822) and C. marulioides (Bleeker, 1851) (Perciformes: Channidae) in Thailand. Cytologia 83: $115-121$.
Sasaki, M. 1935. Cytological studies in Charophyta II. Morphology of the spermatozoid in Chara and Nitella with special reference to the structure of the motile apparatus. Cytologia 6: 492-495.

Senavongse, R., Saensouk, S. and Saensouk, P. 2018. Comparative karyotype analysis in five strains of Colocasia Esculenta (L.) Schott (Araceae) in Thailand. Cytologia 83: 169-173.

Shibuta, M. K. and Matsunaga, S. 2019. Seasonal and diurnal regulation of flowering via an epigenetic mechanism in Arabidopsis thaliana. Cytologia 84: 3-8.

Shimahara, Y., Kutsuna, N., Hasezawa, S. and Kojo, K. H. 2019. Quantitative evaluation of stromule frequency at hourly intervals in Arabidopsis stomatal guard cell chloroplasts. Cytologia 84: 31-35.

Shinke, N. and Shigenaga, M. 1933. A histochemical study of plant nuclei in rest and mitosis. Cytologia 4: 189-221.

Singh, V., Gupta, R. C., Sharma, K., Sharma, V., Sharma, M. and Kaur, K. 2018. Male meiotic studies in 29 species of Lamiaceae from Sirmaur district of Himachal Pradesh, India. Cytologia 83: 235-243.

Sinha, J. P. and Ahmed, S. 1973. A study on the cytology and lifehistory of Cladophora uberrima Lambert. from Ranchi, India. Cytologia 38: 99-105.

Sugiyama, R. 2019. Stable capsaicinoid biosynthesis during the fruit development stage of Capsicum baccatum. Cytologia 84: 309-312.

Sumida, S., Lyman, H., Kiyohara, N. and Osafune, T. 2007. Mechanism of conversion from heterotrophy to autotrophy in Euglena gracilis. Cytologia 72: 447-457.

Supiwong, W., Getlakha, N., Chaiphech, S., Pinthong, K., Phimphan, S. and Tanomtong, A. 2018. Nucleolar organizer regions polymorphism and karyological analysis of black lancer, Bagrichthys majusculus (Siluriformes, Bagridae) in Thailand. Cytologia 83: 193-199.

Takano, H., Tsunefuka, T., Takio, S., Ishikawa, H. and Takechi, K. 2018. Visualization of plastid peptidoglycan in the charophyte alga Klebsormidium nitens using a metabolic labeling method. Cytologia 83: 375-380.

Takase, D. and Suzuki, M. G. 2018. Analysis of sex-specific regulation of the dunce gene in the Drosophila melanogaster central nervous system. Cytologia 83: 345-346.

Takeshita, T., Ota, S., Takeda, K., Yamazaki, T. and Kawano, S. 2015. A simple method for measuring the starch and lipid contents in the cell of microalgae. Cytologia 80: 475-481.

Timme, R. E., Bachvaroff, T. R. and Delwiche, C. F. 2012. Broad phylogenomic sampling and the sister lineage of land plants. PLoS One 7: e29696.

Toyoda, Y. and Matsunaga, S. 2019. Lysine-specific demethylase epigenetically regulates human and plant phenomena. Cytologia 84: 295-298.

Tütüncü, E., Yalçin, E., Acar, A., Yapar, K. and Çavuşoğlu, K. 2019. Investigation of the toxic effects of a carbamate insecticide methiocarb in Allium cepa L. Cytologia 84: 113-117.

Uchida, H., Kato, K., Suzuki, K., Yokota, A., Kawano, S., Matsunaga, S. and Okada, S. 2018. Algal genes encoding enzymes for photosynthesis and hydrocarbon biosynthesis as candidates for genetic engineering. Cytologia 83: 7-17.

Ueda, K. 1956. Structure of plant cells with special references to lower plants I. Mitosis in Spirogyra setiformis. Cytologia 21: 384-390.

Ueda, K. 1958. Structure of plant cells with special reference to lower plants III. A cytological study of Euglena gracilis. Cytologia 23: 56-67.

Ueda, K. 1960a. Structure of plant cells with special reference to lower plants IV. Structure of Trachelomonas sp. Cytologia 25: 8-16.

Ueda, K. 1960b. Structure of plant cells with special reference to lower plants V. Nuclear division in Oedogonium sp. Cytologia 
25: $450-455$.

Ueda, K. 1961. Structure of plant cells with special reference to lower plants VI. Structure of chloroplasts in algae. Cytologia 26: 344-358.

Ueda, K. 1966. Fine structure of Chlorogonium elongatum with special reference to vacuole development. Cytologia 31: 461-472.

Verma, B. N. 1980. Karyotype analysis in three species of Rhizoclonium Kütz. Cytologia 45: 433-440.

Verma, S. and Srivastava, A. 2018. Bioassessment of genotoxicity due to flux in soil nitrogen dynamics caused by addition of ammonium nitrate. Cytologia 83: 271-275.

Vigani, M., Parisi, C., Rodríguez-Cerezo, E., Barbosa, M. J., Sijtsma, L., Ploeg, M. and Enzing, C. 2015. Food and feed products from micro-algae: Market opportunities and challenges for the EU. Trends Food Sci. Technol. 42: 81-92.

Watanabe-Asaka, T., Oda, S. and Mitani, H. 2018. Development of a misrepair visualization assay in the live embryo of Oryzias latipes by partial duplication system. Cytologia 83: 221-222.

Wickett, N. J. et al. 2014. Phylotranscriptomic analysis of the origin and early diversification of land plants. Proc. Natl. Acad. Sci. U.S.A. 111: E4859-E4868.

Wodniok, S., Brinkmann, H., Glöckner, G., Heidel, A. J., Philippe, H., Melkonian, M. and Becker, B. 2011. Origin of land plants: Do conjugating green algae hold the key? BMC Evol. Biol. 11: 104.

Yamaha, G. and Suita, N. 1940. Über die wirkung verschiedener pufferlösungen auf die Spirogyra-zellen. Cytologia 10: 371-381.

Yotsuyanagi, Y. 1953. Recherches sur les phénomènes moteurs dans les fragments de protoplasme isolés I. Mouvement rotatoire et le processus de son apparition. Cytologia 18: 146-156.

Yue, D., You, F. and Snyder, S. W. 2014. Biomass-to-bioenergy and biofuel supply chain optimization: Overview, key issues and challenges. Chem. Eng. Technol. 66: 36-56. 